\title{
Anterior cruciate ligament haemangioma
}

\author{
Satvik N Pai (1) , ${ }^{1}$ Prakash Ayyadurai, ${ }^{2}$ Suresh Perumal, ${ }^{2}$ Arumugam Sivaraman ${ }^{2}$
}

'Orthopaedic Surgery, Sri Higher Education and Research, Chennai, Tamil Nadu, India ${ }^{2}$ Arthroscopy and Sports Medicine, Sri Ramachandra Institute of Higher Education and Research, Chennai, Tamil Nadu, India

\section{Correspondence to} Dr Prakash Ayyadurai; prakashortho@outlook.com

Accepted 16 December 2021 Ramachandra Institute of

\section{DESCRIPTION}

A 5-year-old girl was brought with complaints of pain and swelling in her left knee for past 3 years. She had history of fall and injury to her left knee 3 years earlier. Following the injury, the child had intermittent pain and swelling of the knee joint, especially on performing activities like running or jumping. She also experienced minor difficulty in walking. She occasionally had episodes of locking of the joint. On examination, she was found to have lateral joint line tenderness. A fixed flexion deformity of $15^{\circ}$ and a range of movement of $15^{\circ}-100^{\circ}$ was noted. Thigh muscle was also present. Lachman's test, anterior and posterior drawer tests, McMurray's test, Apley's grinding test and varus and valgus stress tests were all negative.

Radiographs of the knee joint appeared normal. MRI of the knee joint showed a cystic lesion in the anterior compartment of the knee originating from the anterior cruciate ligament (ACL) in the intercondylar notch (figure 1A). The lesion appeared hypointense in T1-weighted images and hyperintense in T2-weighted images (figure 1B,C). The rest of the ACL appeared mildly thickened and oedematous. On arthroscopy, a $1.5 \times 1 \mathrm{~cm}$ cherry red nodular mass was noted in the intercondylar notch originating from the ACL (figure 2). The mass was excised arthroscopically and all remaining capillaries were ablated (video 1). The histopathological examination revealed closely packed spindle cells with spaces filled with blood, consistent with capillary haemangioma. Postoperatively, the child was started on isometric muscle strengthening exercises and mobilised on the first postoperative day. At last follow-up, 2 years following the surgery, she was found to have no recurrence of symptoms, and had an excellent Tegner Lysholm Knee Score of 96.

Haemangioma involving the ACL is extremely rare with only one case being previously reported. These benign tumours are a type of intra-articular synovial haemangioma, which are in itself quite rare. $^{2}$ These are a rare cause of knee pain and

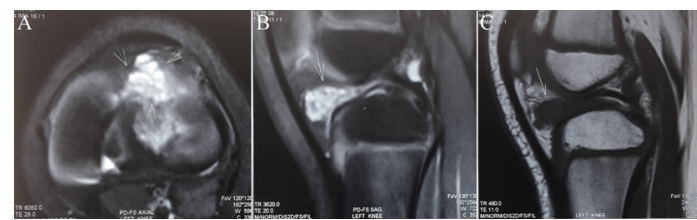

Limited 2022. No commercial re-use. See rights and permissions. Published by BMJ.

To cite: Pai SN, Ayyadurai P, Perumal $\mathrm{S}$, et al. BMJ Case Rep 2022;15:e248058. doi:10.1136/bcr-2021248058
Figure 1 MRI of the knee joint with (A) axial section showing a nodular lesion arising from the intercondylar notch region. (B) T2-weighted MRI sagittal section showing a hyperintense nodular lesion attached to the anterior cruciate ligament. (C) T1-weighted MRI sagittal section showing the lesion to be hypointense.

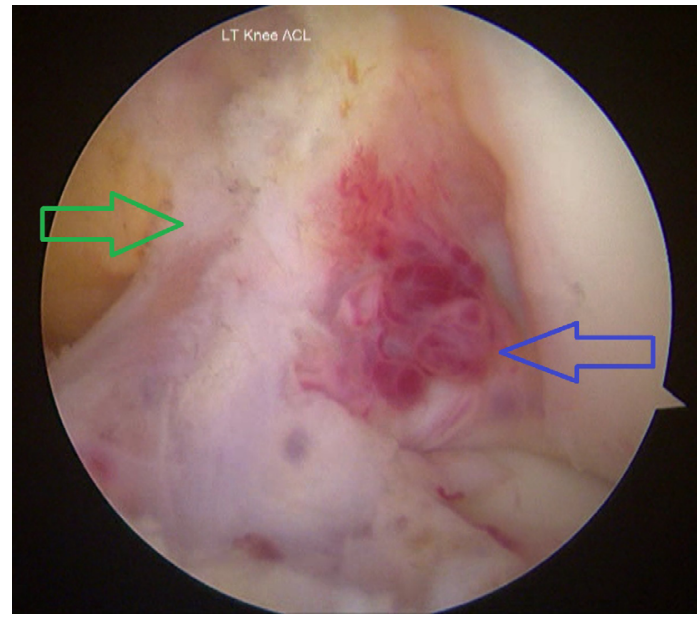

Figure 2 Arthroscopic finding of a $1.5 \times 1 \mathrm{~cm}$ cherry red nodular mass (blue arrow) originating from inferior surface of the anterior cruciate ligament (green arrow).

swelling which are difficult to diagnose owing to their non-specific symptoms and signs. MRI remains the investigation of choice for diagnosis. ${ }^{3}$ MRI helps to differentiate these from synovial chondromatosis, pigmented villonodular synovitis and gouty tophi. For a lesion involving the ACL like in our case, the closest differential to be considered was a ganglion cyst involving the ACL. ${ }^{4}$ It has a similar shape, size and can involve the ACL. It can be differentiated from ACL haemangioma by a fatsuppressed, contrast-enhanced MRI which shows a thin, rim-enhancing feature of ganglion cysts, or by histopathological examination. ${ }^{5}$ The available literature suggests arthroscopic excision as the preferred modality for treatment of ACL haemangioma/intraarticular haemangioma over open resection and synovectomy. ${ }^{12}$

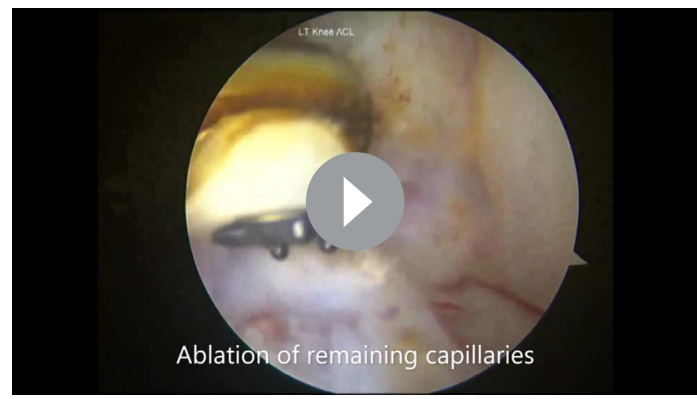

Video 1 Arthroscopy of the knee joint showing a cherry red nodular mass attached to the surface of the anterior cruciate ligament, consistent with the appearance of a capillary haemangioma. The haemangioma was excised and remaining capillaries ablated. 


\section{Patient's perspective}

We are glad that our daughter has not had any problems after the surgery and has been able to do all the activities that she was not able to do earlier due to the pain and swelling.

\section{Learning points}

Intra-articular synovial haemangioma is a rare cause of pain and swelling of the knee joint which can infrequently involve the anterior cruciate ligament.

- MRI is the diagnostic investigation of choice.

- Arthroscopic excision is the preferred modality of treatment.

Contributors SNP and PA obtained the digital images of all investigations of the patient, were responsible for the writing of the draft of the manuscript, and obtained informed consent from the parents of the patient for this publication. SP was responsible for editing of surgical video, and review of manuscript. AS was the chief surgeon under whom the patient was evaluated, performed the surgical procedure, and reviewed the article. All authors were involved in the patient care.
Funding The authors have not declared a specific grant for this research from any funding agency in the public, commercial or not-for-profit sectors.

Competing interests None declared.

Patient consent for publication Consent obtained from parent(s)/guardian(s). Provenance and peer review Not commissioned; externally peer reviewed.

Case reports provide a valuable learning resource for the scientific community and can indicate areas of interest for future research. They should not be used in isolation to guide treatment choices or public health policy.

\section{ORCID iD}

Satvik N Pai http://orcid.org/0000-0002-3621-150X

\section{REFERENCES}

1 Tzurbakis M, Mouzopoulos G, Morakis E, et al. Intra-articular knee haemangioma originating from the anterior cruciate ligament: a case report. J Med Case Rep 2008;2:254.

2 Okahashi K, Sugimoto K, Iwai M, et al. Intra-articular synovial hemangioma; a rare cause of knee pain and swelling. Arch Orthop Trauma Surg 2004;124:571-3.

3 Guler I, Nayman A, Koplay M, et al. Synovial Hemangioma of the knee joint: magnetic resonance imaging findings. Pol J Radiol 2015;80:450-2.

4 Ng WHA, Griffith JF, Hung EHY, et al. Imaging of the anterior cruciate ligament. World I Orthop 2011;2:75-84.

5 Kim MG, Kim BH, Choi JA, et al. Intra-articular ganglion cysts of the knee: clinical and MR imaging features. Eur Radiol 2001;11:834-40.

Copyright 2021 BMJ Publishing Group. All rights reserved. For permission to reuse any of this content visit https://www.bmj.com/company/products-services/rights-and-licensing/permissions/

BMJ Case Report Fellows may re-use this article for personal use and teaching without any further permission.

Become a Fellow of BMJ Case Reports today and you can:

- Submit as many cases as you like

- Enjoy fast sympathetic peer review and rapid publication of accepted articles

- Access all the published articles

- Re-use any of the published material for personal use and teaching without further permission

Customer Service

If you have any further queries about your subscription, please contact our customer services team on +44 (0) 2071111105 or via email at support@bmj.com.

Visit casereports.bmj.com for more articles like this and to become a Fellow 